\title{
Kadınların Rekreatif Alanlarda Fiziksel Aktivite Yapma Amaçları ve Karşılaştıkları Sorunlar
}

\author{
Making Goals Physical Activity of Women and \\ Challenges Faced in Recreactional Areas
}

\author{
Araştırma Makalesi
}

Aynur YILMAZ1, Mehmet ULAŞ 2

1Gazi Üniversitesi, Beden Eğitimi ve Spor Yüksekokulu

2Mehmet Akif Ersoy Üniversitesi, Beden Eğitimi ve Spor Yüksekokulu

\section{öz}

u araştırmanın amacı, rekreatif alanlarda fiziksel aktiviteye katılan kadınların bu alanlarda fiziksel aktivite yapma nedenleri ve karşılaştıkları problemleri tespit etmektir. Araştırma 2014 yılında Kırıkkale il Merkezi'nde rekreatif alanlarda fiziksel aktivite yapan sekiz kadın katılımcı ile gerçekleştirilmiştir. Çalışma grubu seçiminde amaçlı örnekleme yöntemlerinden kolay ulaşabilir örneklem kullanıImıştır. Veriler yarı yapılandırıımış görüşme formu ile toplanmış olup, içerik analizine tabi tutulmuştur. İçerik analizi sonucunda dört tema elde edilmiştir. Bu temalar: fiziksel aktivite yapma amaçları, rekreatif alanları tercih sebepleri, rekreatif alanlarda karşılaştıkları sorunlar, sorunlarla baş etme yollarıdır. Araştırma sonucunda; kadınların fiziksel aktivite yapmalarında sağlık ve fiziksel görünümün önemli iki kriter olduğu görülmüştür. Belediyeler tarafından halkın aktivite yapmasına fırsat sunan rekreatif

ABSTRACT

The aim of this study is having an understanding the reasons for why the women who participate in physical activities in recreaction areas. In addition to this, this study also aimed to understand the difficulties which these women are faced with. The sample of the study consists of eight women who do physical activities in recreation areas in the city of Kırıkkale. Easily accessible sample which is one of the methods purposive sampling was used in the selection of working group. Data was gathered via a semi structured interview guide. In the analysis of the data, content analysis was used. Four themes were collected at the end of the study. These themes are the purpose of doing physical activity, the reasons for choosing recreactive areas, the problems encountered in recreational areas and strategies coping with problems. As a result of the study, it was found that being healhty and having a good physical appearance are found as 
alanların kadınlar tarafından tercih edilmesinde bu alanların sosyalleşme fırsatı sunması, maddi açıdan kadınlara yük getirmemesi gibi faktörlerden dolayı tercih edildiği, aktivite alanlarının fiziksel ve çevresel olarak uygun koşullara sahip olmamasının kadınların bu aktivitelere sınırlı katılımına sebep olduğu sonucuna ulaşılmıştır.

\section{Anahtar Kelimeler}

Fiziksel aktivite, Rekreasyon alanları, Kadın the reasons why they participate in physical activities. The reasons for why woman prefer recreactive areas, whih are provided by municipality, are having a chance to be social and being cheeper. On the other hand, unpreferable reasoans are found as limited physical and environmental factors.

\section{Key Words}

Physical Activity, Recreation Areas, Woman

okul ve iş başarısı üzerinde olumlu etkiye sahip olması gibi sosyal ve ruhsal olarak da bireylerin yaşamına olumlu katkılarının olması (Schmitter, 2003) fiziksel aktiviteye katılımı etkileyen diğer faktörlerdir.

Son dönemlerde ülkemizde ortaya çıkan "toplumsal cinsiyet eşitliği" yaklaşımları spor alanına olumlu yansımış ve spor ve serbest zaman etkinliği olarak fiziksel aktivitelere katılımda kadın bireylerin de en az erkek bireyler kadar rağbet gösterdikleri gözlenmiştir. "Toplumsal cinsiyet kavramı kadın ve erkek arasındaki biyolojik farklılıklardan ziyade kültürel ve psikolojik farklılıkları ifade ederken, bu farklılıklara dayalı olarak kadından ve erkekten beklenen toplumsal rol ve sorumluluklar toplumsal cinsiyet rolü kavramı ile tanımlanmaktadır. Bu bağlamda kadınlık ve erkeklik, toplum tarafından kadına ve erkeğe uygun görülen toplumsal cinsiyet rollerini ifade etmektedir" (Koca, 2006). Toplum tarafından kadınlara biçilen cinsiyet rollerinin çağın gerektirdiği gelişmeler, küreselleşme, kentleşme, devletlerin uyguladığı politikalar (WHO, 1998); kadınların eğitim düzeylerinin yükselmesi, çalışma hayatına daha çok katımaları, ailedeki bir takım fonksiyonların toplumsal kurumlara aktarılması (Günay ve Bener, 2011) gibi gelişmelerden dolayı olumlu yönde değişmiş̧ir. Bu olumlu değişim kadınların günlük hayatlarında fiziksel aktiviteye katılımına da olumlu yönde yansımıştır. Kadınların bir işte çalışıp çalışmama durumu, eğitim seviyeleri ve meslekleri, kadınların anne-baba ve eşlerinin eğitim seviyeleri, kadınların aylık gelir seviyeleri, aile yapısı, aile sorumlulukları, psikolojik iyi olma hali (Weinberg ve Goul, 2014), 
ailenin spora katılımı, spor tesislerinin durumu, yaşanılan sosyal çevrenin uygun olması, yakın çevrenin ve arkadaş gruplarının etkisi, kadınların kilo durumları, televizyon etkisi, zaman olgusu ve bu konudaki ilgi ve istekleri fiziksel aktiviteye katılımlarını etkileyen nedenlerdir (Tatar ve diğ., 2009; Aytan, 2013; Koca ve diğ., 2009). Ülkemizde kadının spor ve fiziksel etkinliklere katılımının artışına parelel olarak kadınların bu tür etkinliklere katıımını toplumsal cinsiyet eşitliği yaklaşımıyla inceleyen araştırmalarda da gözle görülür bir artış olmuştur. Bu araştırmalarda kadınların spor ve fiziksel aktiviteye ilgileri, katılım sebepleri (Koruyucu Aytan, 2013; Tatar, Tozoğlu ve Pehlivan, 2009); kadın sporcuların yer aldığı günlük gazete haberlerinin sunum biçimleri (Arslan ve Koca, 2006; Cantek ve Yarar, 2009); sporda kadınlar ve sorunları (Yaprak ve Amman, 2009); kadınların olimpik hareketteki yerleri (Özbey ve Güzel, 2011); fiziksel aktiviteye katılımın kadınların gündelik yaşamlarında ne tür değişimler yarattığını (Bulgu, Arıtan ve Aşcı, 2007); kadınların düzenli fiziksel aktivite (DFA) alışkanlığını, seçilen aktivite türünü, aktivitenin süresi ve sıkı̆̆ını, aktiviteye katııma ya da katılmama nedenlerini (Şahin ve diğ., 2014); kadınların boş zamanlarında fiziksel aktiviteye katıımı ve katııımını engelleyen faktörleri (Koca ve diğ. 2009) araştıran çalışmalar bulunmaktadır.

$\mathrm{Bu}$ olgular bağlamında çalışmanın amacı; Kırıkkale ilindeki rekreasyon alanlarında fiziksel aktivite yapan kadınların fiziksel aktivite yapma amaçlarının, rekreasyon alanları tercih etme durumlarının, rekreasyon alanlarda karşılaştıkları sorunların ve bu sorunlarla baş etme yollarının neler olduğunun belirlenmesidir. Bu değerlendirmeler toplumsal cinsiyet eşitliği yaklaşımları açısından yorumlanmaya çalışımıştır.

\section{YÖNTEM}

Araştırmanın Modeli: Kadınların rekreatif alanlarda spor yapmayı tercih etme nedenleri ve karşılaştıkları problemlerin incelendiği çalışmada, araştırmacıya konu ile ilgili ayrıntılı ve derinlemesine veri toplama, katılımcıların bireysel algıları, deneyimleri ve bakış açılarını doğrudan öğrenme, mevcut durumları anlama ve açıklama amacı taşıyan nitel araştırma yaklaşımlarından (Patton, 2001) durum çalışması deseni kullanılmıştır. Bir örneğin, olgunun veya sosyal birimin, yoğun, bütüncül bir biçimde tanımlanması ve analizi (Merriam, 2013) olarak ifade edilen durum çalışması desenlerinden birisi olan iç içe geçmiş tek durum deseninden faydalanılmıştır (Yin, 2003). Nitel araştırma yaklaşımı kullanılan bu çalışmadaki işlem basamaklarını gösteren akış şeması Şekil 1'de gösterilmiştir.

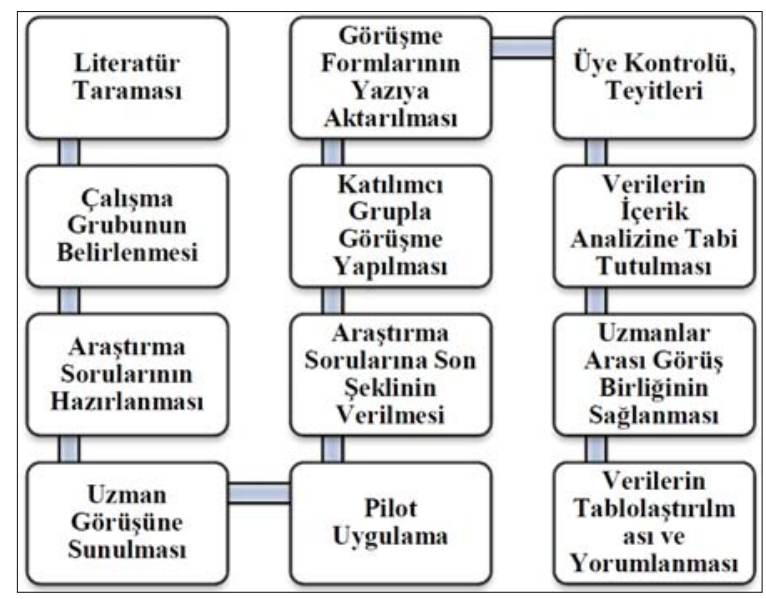

Şekil 1. Araştırma konusuyla ilgili veri toplama süreci akış şeması

Çalışma Grubu: Bu çalışmaya, 2014 yılında Kırıkkale il merkezindeki rekreatif alanlarda fiziksel aktivite yapan 8 kadın katılmıştır. Kırıkkale yaklaşık iki yüz bin nüfusa sahip ve sosyo-ekonomik açıdan gelişmekte olan iller arasında yer almaktadır (Filiz, 2005). Çalışma ildeki en yoğun olarak kullanılan ve en merkezi alanda yer alan Atatürk Bulvarı parkında yapılmıştır. Çalışmada, araştırma konusu hakkında detaylı bilgi toplaması ve verilerin niteliğinin yüksek olması amacıyla, araştırma amacına hizmet edecek örnek birimleri kapsayan (Baş ve Akturan, 2013; Creswell, 2013) ve örnekleme hızlı ve kolay bir şekilde ulaşarak zaman, enerji ve maddi kaynak tasarrufu sağlayan (Patton, 2001) amaçlı örneklem yöntemlerinden kolay ulaşılabilir durum örneklemesi kullanılmıştır. Katıımcılara ilişkin kişisel bilgiler Tablo 1'de gösterilmiştir. 
Tablo 1. Araştırmaya katılan katılımcılara ilişkin kişisel bilgiler

\begin{tabular}{cccccc}
\hline *Rumuz & Yaş & Öğrenim Durumu & Meslek & $\begin{array}{c}\text { Medeni } \\
\text { Durum }\end{array}$ & $\begin{array}{c}\text { Çocuk } \\
\text { Sayısı } \\
\text { Sayısı }\end{array}$ \\
\hline Hülya & 32 & Lise & Çalışmıyor & Bekar & - \\
\hline Elif & 24 & Lisans & Öğrenci & Bekar & - \\
\hline Zahide & 32 & Lise & Ev Hanımı & Evli & 1 \\
\hline Gönül & 41 & Lise & Ev Hanımı & Evli & 2 \\
\hline Meltem & 36 & Ortaokul & Ev Hanımı & Evli & 2 \\
\hline Zeynep & 44 & Lise & Ev Hanımı & Evli & 3 \\
\hline Sevinç & 52 & Ortaokul & Esnaf & Evli & 3 \\
\hline Şengül & 26 & Lisansüstü & Memur & Bekar & - \\
\hline
\end{tabular}

Yaş Ortalama: 35,8 (Min:24, Mak:52)

*Yukarıda belirtilen isimler çalışma kapsamında yer alan katılımcıları temsil eden rumuzlardır.

Tablo 1'de katılımcıların bazı kişisel bilgilerine yer verilmiştir. Bu bilgilere göre, araştırmaya dahil edilen kadınların yaşları 24 ile 52 arasında değişmektedir, yaş ortalamaları 35,8'dir. Öğrenim durumuna göre; katılımcıların 4'ü Lise, 2'si Ortaokul, 1'i Lisans ve 1'i Lisansüstü mezunudur. Bu etkinliklere katılımda katılımcıların gelir durumunun da bir kriter olduğu dikkate alınırsa onların mesleki durumları da bulguları yorumlama da önemli olacaktır. Katıııcıların 4'ü ev hanımı, diğerleri öğrenci, esnaf, memur ve çalışmıyordur. Medeni durumlarına göre ise katılımcıların 3'ü bekar, 5'i ise evlidir. Evli olan katılımcıların sahip oldukları çocuk sayısı ise 1 ile 3 arasında değişmektedir.

Veri Toplama Araçları: Araştırma konusuna yönelik veri toplamak amacıyla görüşme tekniği kullanılmıştır. Gözlemleyemediğimiz davranışlar, duygular veya insanların etrafındaki dünyayı nasıl ifade ettiklerini öğrenmek amacıyla kullanılan görüşme (Merriam, 2013); insanların neyi, neden düşündüklerini, duygu, tutum ve hislerinin neler olduğunu, davranışlarını yönlendiren faktörleri ortaya çıkarmayı sağlayan bir araçtır (Ekiz, 2009). Bu çalışmada, Bogdan ve Biklen (2003)'in önerdiği ve katılımcıların belirli konu ile ilgili düşüncelerini özgürce ifade etmelerine fırsat sunan yarı yapılandırılmış görüşme tekniği kullanılmıştır. Yarı yapılandırılmış görüşme tekniği, önceden düşünülmeyen ve görüşme sırasında ortaya çıkabilen yeni durumlarda görüş- mede bazı değişmeler yapmaya olanak sağlayan bir tekniktir (Özgüven, 2004).

Görüşme formu hazırlanmadan önce konu ile ilgili yapılmış çalışmalar (Bulgu ve diğ., 2007; Culp, 1998; King, 2000; Koca ve diğ., 2009; Şahin ve diğ., 2014) incelenmiş, araştırmanın amacına hizmet eden soruların yer aldığı yarı yapılandırılmış bir görüşme formu hazırlanmıştır. Hazırlanan soruların kapsam geçerliğini sağlamak ve soruların anlaşılırlığını test etmek amacıyla sorular uzman görüşüne sunulmuştur. Görüşme formundaki sorular ölçme ve değerlendirme alanından 2, Türkçe eğitimi alanından 1 ve konu alanı uzmanı 2 olmak üzere toplamda 5 uzman görüşüne sunularak soruların geçerliğine kanıt sağlanmıştır. Her bir madde "gerekli", "düzeltilmeli" ya da "gereksiz" şeklinde derecelendirilmiş ve uzmanlar tarafından değerlendirilmeye tabi tutulmuştur. Görüşme formundaki soruların basit ve anlaşılır olması ve eksik kalan noktaların tespit edilmesinde uzman görüşlerine sıkça başvurulmuştur. Çalışma grubuna benzer özelliklere sahip kişiler üzerinde pilot uygulama yapılarak anlaşılmayan, eksik kalan noktalar tekrar gözden geçirilmiş ve hem uzmanlar hem de pilot uygulama sonucundaki geri bildirimler dikkate alınarak görüşme formuna son şekli verilmiştir. Veri toplama aracı iki bölümden oluşmuştur. İlk bölümünde; katılımcıların yaşı, öğrenim durumu, mesleği, medeni durumu, çocuk sayısı ve düzenli spor yapma durumunu tespit etmeye yönelik 
kişisel bilgilere yer verilmiştir. İkinci bölümünde ise, konuyla ilgili literatür taraması ve uzman görüşleri sonucunda oluşturulan sorular yer almıştır. Yapılan görüşmelerde katılımcılara şu sorular yöneltilmiştir:

- Fiziksel aktivite yapma amacınız nedir?

- Fiziksel aktivite yapmak için rekreatif alanları tercih etme nedenleriniz nelerdir?

- Fiziksel aktivite yaparken bu alanlarda ne tür problemlerle karşılaşıyorsunuz?

- Bu problemlerin giderilmesine yönelik önerileriniz nelerdir?

- Kadınlar bu alana yeterince katılım sağıyor mu, onların daha fazla katılımlarını sağlamak için neler yapılabilir?

Çalışmaya sekiz kadın gönüllülük ilkesine göre dahil edilmiştir. Katılımcı sayısının bu rakamla sınırlandırılmasında, elde edilen verilerin benzerlik taşıması ve yeni verilerin elde edilememesi kriter olarak alınmıştır. Bu uygulama farklı günlerde yapılmış ve toplamda üç günde tamamlanmıştır. Katılımcılara çalışmanın amacı açıklanmış, görüşmeyi istedikleri zaman sonlandırabilecekleri, elde edilen verilerin sadece bilimsel amaçlı kullanılacağı ifade edilmiştir. Görüşmeler esnasında veri kaybını aza indirgemek amacıyla görüşmeler ses kayıt cihazı aracılığıyla kayıt altına alınmıştır. Görüşmeler yaklaşık olarak 20 ile $30 \mathrm{dk}$. arasında değişmiştir.

Verilerin Analizi: Veriler betimsel ve içerik analiz tekniği kullanılarak analiz edilmiştir. Betimsel analiz tekniğinde veriler araştırma sorularının ortaya koyduğu temalara göre düzenlenebileceği gibi, görüşmede yer alan sorular dikkate alınarak da sunulabilir. Betimsel analizde görüşmeye katılanların görüşlerini çarpıcı bir biçimde yansıtmak amacıyla doğrudan alıntılara sık sık yer verilir (Yıldırım ve Şimşek, 2011). Elde edilen veriler derinlemesine içerik analizine de tabi tutulmuştur. İçerik analizinin amacı, sayıca fazla olan metin yığınında, araştırma sorusu açısından önem arz eden ortak bilgileri tespit etmek ve değerlendirmektir (Gökçe, 2006).

Verilerin analizi için öncelikli olarak katı- lımcılardan elde edilen görüşme kayıtları araştırmacılar tarafından metne aktarılmıştır. Ses kayıtları tekrar dinlenerek yazılı metinlerdeki eksiklikler giderilmiştir. Katılımcılardan elde edilen görüşme formlarına katılımcıları temsil eden rumuz isimler verilmiştir. Görüşme metinleri satır satır okunmuş ve araştırmacılar tarafından araştırma problemi kapsamında kodlama yapılmıştır. Çünkü nitel çözümlemede verilerin içeriklerini keşfetmeye yönelik çözümleme için kodlama, ilk ve asli işlemdir (Punch, 2005). Görüşme metinleri kodlanırken, her soruya karşılık katıımcıların verdiği cevaplar gözden geçirilmiş, metinlerin kenarına notlar alınmış, kodlamalar yapılmıs, tekrar tekrar metinler okunarak kodların yer aldığı bir kod listesi oluş̧urulmuşstur. Çalışmanın amacı ve bu amaca ulaşmak için oluşturulan alt amaçlar dikkate alınarak, elde edilen kod yığınları mantıklı şekilde ortak özeliklere göre bir araya getirilerek, alt kategori ve kategorilere ulaşılmıştır. Bu süreçte, bu kategori ve alt kategoriler birbirleri ile ilişkilendirilerek tablolaştırılmıştır. Elde edilen bulguların yorumlanmasında katılımcı görüşleri ve ilgili alan yazından faydalanılmıştır.

Araştırmanın geçerlik ve güvenirliğine yönelik olarak, Yıldırım ve Şimşek (2011) nitel araştırmada geçerliği "toplanan verilerin ayrıntılı olarak rapor edilmesi ve araştırmacının sonuçlara nasıl ulaştığının açıklaması nitel bir araştırmada geçerliğin ölçütleri arasında yer almaktadır" şeklinde ifade etmektedir. Geçerlik için, araştırma süresince veri toplama aracının nasıl oluşturulduğunu, soruların konuyu açıklayabilecek kapsam geçerliği nasıl sağladığını, verilerin nasıl analiz edildiği aşama aşama açıklanmıştır. Ayrıca katılımcılardan elde edilen görüşlere yer verilerek, analizler neticesinde elde edilen bulguların geçerliği sağlanmaya çalışıımıştır. Verilerin analizinde uzmanlar arası görüş birliğine bakılmıştır. Bunun için araştırmacı haricinde bir alan uzmanına da katılımcılardan elde edilen görüşme formları verilmiş ve formların analiz edilmesi sağlanmıştır. İki uzman birbirinden bağımsız verileri analiz etmiştir. Araştırmacı ve uzman arasındaki uyuma bakılmıştır. Uyuşmazlıklar 
kodlayıcılar arasında görüşülerek giderilmiştir. Miles ve Huberman (1994)'ın formüle ettiği güvenirlik kat sayısına bakıımış ve güvenirlik kat sayısı \% 93 olarak bulunmuştur. iç̧erik analizi sonucunda elde edilen kodlar ve bu kodların belirli bir mantık çerçevesinde ortak bir paydada buluştuğu kategorilerin yer aldığı tablolara yer verilmiş, her kategoriye ait frekans gösterilmiştir. Bu bilgiler katıımcı görüşlerine yer verilerek desteklenmiştir.

\section{BULGULAR}

Bu bölümde, kadınların fiziksel aktiviteye katıIımları ile ilgili görüşlerinden ulaşılan bulgu ve yorumlara yer verilmiştir. Verilerin analizi sonucunda dört kategori elde edilmiştir. Bu kategoriler; fiziksel aktivite yapma sebepleri, rekreasyon alanlarını tercih etme sebepleri, fiziksel aktivite yaparken karşılaştıkları problemler ve problemlerle başa çıkma yollarıdır. Kadınların fiziksel aktivite yapma nedenlerine ilişkin elde edilen bulgular Tablo 2'de gösterilmiştir.

Tablo 2'de katılımcıların fiziksel aktivite yapma sebeplerine ilişkin elde edilen 4 alt kat egori gösterilmiştir. Bu kategoriler; Sağlıklı olma $(f=7)$, fiziksel görünüş $(f=5)$, stresten uzaklaşma $(f=4)$ ve sosyalleşme $(f=2)$ dir. Kadınların fiziksel aktivite tercihlerinde ilk sırayı sağlıklı olmanın aldığı görülmektedir. Bu kategoride, katıımcılar fiziksel aktivitenin hareketsiz yaşamdan ve yanlış beslenmeden kaynaklı oluşabilecek kolesterol ve aşırı kilo alımını önlemesi; kadınların menopoz döneminde yaşadıkları problemlerin azalmasına katkı sağlaması; şeker hastalarındaki şeker seviyesini dengelemesi gibi nedenleri ifade etmiştir. Katılımcılardan Gönül, fiziksel aktivite yapma nedeninin sağlıklı olmak olduğunu ifade etmiştir. "...aktivite yapmaya başlamamın nedeni sağlıklı olabilmek ve eski sağlığıma kavuşmaktı. Doktor bana her gün yürüyüş yapacaksın ve kendine zaman ayıracaksın dedi. Bunu 15 yıldır düzenli olarak yapıyorum kendimi iyi ve zinde hissediyorum. Kolesterol açısından, menopoz açısından çok fayda gördüm". Gönül psikolojik hastalığından dolayı doktor tavsiyesi üzerine başladığı fiziksel aktiviteyi 15 yıldır düzenli olarak sürdürdüğünü, rahatsızlığının azalmasının yanı sıra kolesterol ve menopoz gibi sorunlarının da azaldığını belirtmiştir. Mevcut çalışmada Meltem'in de fiziksel aktivite yapma nedeni Gönül ile benzerlik taşımaktadır. Şeker hastalığı olan Meltem doktor tavsiyesi üzerine başladığı aktivitenin şeker seviyesini kontrol altına almasını sağladığını ifade etmiştir. "Doktor tavsiyesi yürüyüş yapmanın şekerin denge tutulması açısından iyi olacağı yöndeydi. Zaten kilom da fazlaydı, istediğim kıyafetleri de giyemediğim için bu aktiviteye devam ettim". Kadınların genelinin fiziksel aktivite yapma nedeni olarak sağlıklı olma beklentisi içerisinde oldukları tespit edilmiştir. Kadınlar sağlıkı olmak için fiziksel aktivite yaptıklarını belirtseler de, aktivite neticesinde kilo vermek, kiloyu dengede tutmak, iyi bir fiziki görünüşe sahip olmak gibi beklentilerinin de olduğu görülmüştür. Ardahan (2013)'ın bireyleri rekreatif spor aktivitelerine motive eden faktörleri incelediği çalışmada, genel olarak kadınların bu sportif aktiviteleri görünüş ve sağlıklı olmak için tercih ettikleri bulgusunu elde etmiştir. Mevcut çalışmamızda da, kadınların sağlıklı olma ve fiziksel görünüşün iyi olması arasında olumlu yönde ilişki kurdukları görülmüştür. İyi bir fiziksel görünüşün kişinin psikolojik sağlığına da olumlu yansıması

Tablo 2. Fiziksel Aktivite Yapma Sebepleri

\begin{tabular}{|c|c|c|c|c|c|c|c|c|c|}
\hline \multirow[t]{2}{*}{ Kategoriler } & \multicolumn{8}{|c|}{ Katılımcılar } & \multirow[t]{2}{*}{ Frekans } \\
\hline & Hülya & Elif & Zahide & Gönül & Meltem & Zeynep & Sevinç & Şengül & \\
\hline Sağlıklı olma & $\checkmark$ & $\checkmark$ & $\checkmark$ & $\checkmark$ & $\checkmark$ & $\checkmark$ & & $\checkmark$ & 7 \\
\hline Fiziksel görünüş & $\checkmark$ & $\checkmark$ & $\checkmark$ & & & & $\checkmark$ & $\checkmark$ & 5 \\
\hline Stresten uzaklaşma & $\checkmark$ & & & $\checkmark$ & $\checkmark$ & & $\checkmark$ & & 4 \\
\hline Sosyalleşme & & & & & $\checkmark$ & $\checkmark$ & & & 2 \\
\hline
\end{tabular}


olacağına yönelik katılımcı görüşleri mevcuttur.

Fiziksel aktiveye iyi bir fiziksel görünüşe sahip olmak için başladığını ifade eden Zahide, fiziksel görünüşün sağlık üzerinde olumlu etkisi olduğunu belirtmiştir. "Fiziksel görünüş için yapıyorum sağık ikinci planda kalıyor. Iyi bir görünüşe sahip olduğum zaman kendimi mutlu ve huzurlu hissedeceğimden sağlığım da iyi olacaktır. Fiziksel görünüş diyorum. Çünkü insan ne kadar kendini dış görünüş olarak iyi hissederse özgüveni de o kadar iyi olur". Öğrenci olan Elif, fiziksel görünüşün kişinin kendisini mutlu hissetmesini sağladığı, kendisiyle daha barışık olduğu ve toplumda kendine bir statü kazandırmaya katkısını olduğunu ifade etmiştir. “ ...iyi bir görünüş kişinin kendisini daha iyi ve mutlu hissetmesine neden olur. Kişi kendisiyle barışık olur ve toplum karşısında daha bir saygınlık kazanıyor". Fiziksel görünüşün sağlıkla ilişkisine değinen kadınların, kendilerine bu aktivitelere katılım sağlama konusunda zaman ayırma durumunun tespiti önem taşımaktadır.

Kilo vermek, kiloyu dengede tutmak ve güzel görünüşe sahip olmak kadınların iyi bir görünüşe ve sağlıklı olma amacına hizmet ettiği bulgusu elde edilmiştir. Bunun için fiziksel aktivite ya da spor yapan kadınların sporu güzelleşme ve güzelleştirme aracı olarak gördükleri söylenebilir. Aktivite zayıf bedene ulaşmanın yollarından biridir. Böyle bir amaçla yapıldığında, güzellikle eşdeğer görülen sağlık anlayışının oluşmasına katkı sağlamaktadır (Hacısoftaoğlu ve Bulgu, 2012). Kadınların bu alanlarda yürüyüş ve jogging yaptıkları göz önüne alındığında, Koruyucu Aytan (2013)'nın çalışmasında elde ettiği bulgu ile benzerlik taşımaktadır. Çalışmada kadınların formda kalmak için aerobik, step, yürüyüş ve jogging gibi fiziksel aktiviteleri tercih ettikleri tespit edilmiştir. Beden imajının olumlu olması, benlik saygısını yükseltir (Oktan ve Şahin, 2010). Kişinin özgüveni yükselir. Lisansüstü öğrenime sahip olan Şengül'ün bu konuyla ilgili görüşü şu şekildedir:

“...Kişinin fiziki yapısının şekillenmesi ve korunmasında önemlidir. Bunun dışında insan psikolojisi üzerinde fiziksel görünüşün etkisi olduk- ça önemlidir. İyi bir görünüşe sahip olmak kişinin özgüven duygusunu arttırır ve kişinin kendisiyle barışık olması açısından avantaj sağlar..." (Şengül).

Fiziksel görünüşün şekillenmesinde ve kilonun dengede tutulmasında fiziksel aktivitenin gerekli ve önemli olduğu katılımcılar tarafından ifade edilmiştir. İyi bir dış görünüşe sahip olmanın kendilerini fiziksel, sosyal, psikolojik olarak sağlıklı hissetmelerini sağladığı ve özgüvenleri üzerine pozitif yansımaları olduğunu belirtmişlerdir. Sağlık ve fiziksel görünüşün birbirini olumlu olarak etkilemesi, kadınların bu aktivitelere daha fazla ilgi göstermesini sağlamaktadır.

Mevcut çalışmada, kadınların sosyalleşme amacıyla da fiziksel aktiviteye katılım sağladıkları tespit edilmiştir. Karakuş (2005)'e göre, rekreatif etkinlikler kişilerin sosyalleşmesine katkı sağlamaktadır. Katılımcılardan Zeynep'in bu konudaki görüşü, fiziksel aktivitenin sosyalleşmede önemli olduğu, arkadaşları ile zaman geçirme fırsatı sunduğu yönündedir.

"Sosyalleşme olanağı sunması bu aktivitelere katılmamda önemli. Evde çocuklar olduğu için arkadaşlarımızla bir araya gelme fırsatı çok sık bulamıyoruz. Ama yürüyüş esnasında sohbet edebiliyoruz...(Zeynep)". Ev hanımı ve üç çocuk annesi olan Zeynep, bu etkinliklere katılarak arkadaşları ile zaman geçirebildiğini ifade etmiştir.

Kadınların fiziksel aktiviteye katılım amaçlarına yönelik kadınların amaçlarının farkılık gösterdiği görülmüştür. Fiziksel aktiviteye katılımda sağlık faktörünün öncelikli öneme sahip olduğu tespit edilmiştir. Kadınlar, sağlığı iyi bir dış görünüşle desteklemekte olup, bu iki faktörü birbirini tamamlayan unsurlar olarak nitelendirmişlerdir.

Kadınların fiziksel aktivite yapmak için rekreasyon alanlarını tercih etme sebeplerine ilişkin bulgular Tablo 3'de gösterilmiştir.

Tablo 2'deki bulgular dikkate alındığında, katılımcıların rekreatif alanları tercih etme nedenlerinin 4 kategori altında ele alındığı görülmektedir. Bu kategoriler "sağlık açısından uygunluk $(f=6)$, fiziksel olarak uygunluk ( $f=5)$, sosyalleşme açısından uygunluk $(f=4)$ ve maddi açıdan uygunluk ( $f=2)$ " tur. Kadınların bu alanları tercih 
Tablo 3. Rekreatif Alanları Tercin Etme Sebepleri

\begin{tabular}{|c|c|c|c|c|c|c|c|c|c|}
\hline \multirow[t]{2}{*}{ Kategoriler } & \multicolumn{5}{|c|}{ Katılımcılar } & \multicolumn{4}{|c|}{ Frekans } \\
\hline & Hülya & Elif & Zahide & Gönül & Meltem & Zeynep & Sevinç & Şengül & \\
\hline $\begin{array}{l}\text { Sağlık } \\
\text { Açısından } \\
\text { Uygunluk }\end{array}$ & $\checkmark$ & $\checkmark$ & $\checkmark$ & & & $\checkmark$ & $\checkmark$ & $\checkmark$ & 6 \\
\hline $\begin{array}{c}\text { Fiziksel Açıdan } \\
\text { Uygunluk }\end{array}$ & $\checkmark$ & & $\checkmark$ & $\checkmark$ & $\checkmark$ & & & $\checkmark$ & 5 \\
\hline $\begin{array}{l}\text { Sosyalleşme } \\
\text { Açısından } \\
\text { Uygunluk }\end{array}$ & $\checkmark$ & $\checkmark$ & & & $\checkmark$ & & $\checkmark$ & & 4 \\
\hline $\begin{array}{l}\text { Maddi Açıdan } \\
\text { Uygunluk }\end{array}$ & & & & $\checkmark$ & & $\checkmark$ & & & 2 \\
\hline
\end{tabular}

etme sebepleri arasında ilk sırayı "sağlık açısından uygun olma" almaktadır. Açık alan, bol oksijen, temiz havanın kişinin sağlığı üzerindeki etkisine yönelik içeriğe sahip olan bu kategoriye ait Sevinç'in görüşü şöyledir:

"Açık hava ve bol oksijen olan ortamda spor yapmak beni rahatlattığı için kapalı alanda spor yapmak yerine açık ve özellikle güneşli havada yapmayı tercih ediyorum. Spor salonuna gitme olanağım var ama kapalı alanda kalamadığım için açık alanı tercih ederim..." Açık havanın insan sağlığı ve psikolojisi üzerindeki etkisine dikkat çeken akademisyen Şengül, ev ve iş ortamının kapalı alan olduğu, iş yükünün fazlalığı ve iş hayatında karşılaşılan bazı olumsuzlukların verdiği stresi, açık havada fiziksel aktiviteye katılım sağlayarak en aza indirgediğini ifade etmiştir. “...yürüyüş yapıyorum en 45 dakika her gün düzenli olarak. Buranın açık hava olması beni dinlendiriyor. İs ortamının verdiği stresten uzaklaştırıyor. Nefesim açılıyor. Kendimi yenilenmiş hissediyorum..." Katılımcı görüşlerine göre; bu alanın açık alan olmasının insanın psikolojik sağlığı üzerindeki etkisini ifade ettikleri görülmüştür. North, McCullagh ve Zung (1990)'ın ifade ettiklerine göre; bu alanda yapılan fiziksel aktivite bireylere psikolojik olarak rahatlık, huzur, stresten uzaklaşma ve farklı sosyal ilişkiler kurabilme olanağı sunmaktadır.

Katılımcılar rekreasyon alanını tercih etme sebepleri olarak; bu alanın kendilerine açık hava ve bol oksijen sunması, kendilerini kapalı alanların kasvetli havasından uzaklaştırması, daha mutlu ve huzurlu hissetmelerine firsat sunması olarak belirlenmiştir. Alanın fiziksel olarak bazı eksiklikleri olmasına rağmen (halkın kullanımına sunulan araç-gereçlerin yetersizliği, konum olarak esnafın bulunduğu ve trafiğe yakın olması), bulunduğu konum olarak ulaşımın kolay olması ve diğer rekreasyon alanına göre daha güvenli olması kadınların bu alanı tercih etmesinde önemli unsurlardır. Kırıkkale merkezde fiziksel aktivite yapılabilecek iki rekreasyon alanı mevcuttur. Çalışma kapsamında ele alanın alan, Kırıkkale halkının yoğun katılım sağladığı, merkezi bir noktada olan alandır. Kadınların genelinin bu alanı tercih etme nedenleri fiziksel olarak diğer alana göre daha uygun olmasıdır. Meltem'in bu alanı tercih etme nedenleri evine yakın olması ve daha güvenilir olmasıdır. "... Eve yakın olmasının sağladığı kolay ulaşım, merkezi bir noktada bulunduğu için daha güvenilir olmasıdır". Kadınların bu alanları tercih etmesinde alanın bulunduğu konumun güvenilir olması olduğu tespit edilmiştir. Bu nedenle bu alanlar inşa edilirken, bu kriterin dikkate alınması gereklidir. Kadınların bazıları bu alanların merkezi konumda olmasının yeterli olmadığı, çevresel faktörlerin (etrafta bulunan iş yerleri, kahvehaneler) de bu alanlarda fiziksel aktiviteye katılımda sınırlayıcı olduğu yönündedir. Gönül, “Çevresel faktörlerden dolayı tek başıma gelmeye korkuyorum. Çevre faktörü önemli. Apartman yol ve bazı işletmeler var. Bu durum bana rahatsızlık veriyor. Bu yüzden eşim ve çocuğum ile geliyoruz..." Fiziksel olarak bu 
alanın bulunduğu konum alanı tercih etmede etkilidir, ancak kadınların bazısı bu alana yalnız gelmeye korktuğunu ve bunun için eşi ve çocuğu ile birlikte katıım sağladığını belirtmiştir.

Kadınların fiziksel aktivite için rekreasyon alanlarını tercih etmelerindeki bir diğer sebep, bu alanların kendilerine sosyalleşme olanağı sunmasıdır. Yeni çevre ve arkadaşlıkların etkisi de kadınların bu alanları tercih etme nedenleri arasında gösterilebilir. Sporun birleştirici ve sosyalleştirici etkisi kendisini bu alanlarda da göstermekte, alanda yapılan serbest zaman aktiviteleri kişilerin etkileşimini geliştirmektedir. Bu alanlar, kadınlara farklı kişiler ile tanışma, arkadaşları ile birlikte zaman geçirebilme gibi olanaklar sağlamaktadır. Üniversite öğrencisi olan Elif, bu alanı tercih etme nedeni olarak; alanda farkı kişilerin olması, bunlarla tanışma olasılığının bulunması olduğunu ileri sürmüştür. "...bu alanda farklı kişiler olduğundan insanı daha cazip edici hale geliyor. Onlarla sohbet edebilme olasılığımız oluyor. Yeni arkadaşlıklar oluşabiliyor". Üç çocuk annesi olan Sevinç, bu alanı arkadaşları ile birlikte zaman geçirebilecekleri, sohbet edebilecekleri, aynı zamanda aktivite yapacakları alan olarak nitelendirmektedir. " Arkadaşlarımla görüşebilmem için iyi bir firsat. Hem sporumuzu yapıyoruz hem de arkadaşlar ile zaman geçirebiliyoruz. Zaten tek başıma spor yapmayı sevmiyorum. Arkadaşlar ile daha güzel oluyor. İyi vakit geçiriyoruz".

Kadınların fiziksel aktiviteye katılımında ekonomik olanaklar önemlidir. Mevcut çalışmada; katılımcıların genelinin ekonomik gelirinin olmadığı, ev hanımı ve öğrenci olduklarından ekonomik gelirleri az ya da hiç yoktur. Bu alanlar bedava olarak halkın kullanımına sunulduğundan, maddi açıdan onlara ekstra bir yük getirmemektedir.
Kadının ekonomik özgürlüğü sportif katıımda önemlidir. Tatar, Erdoğan ve Pehlivan (2009) belirli bir ücret karşılığı yapılan spor etkinliklerine maddi olanağı olan kadınların katıııının daha fazla olduğunu belirtmişlerdir. Açık alan egzersiz parkları gerek ekonomik (ücretsiz olması nedeniyle) gerek çevresel, gerek de bir takım sosyal faydalar sağladığından tercih edilmektedir (Şimşek ve diğ., 2011). Ev hanımı olan Gönül bu alanı tercih etme nedenlerinden birisi olarak bu alandaki spor araç ve gereçlerinin kullanımının ücretsiz olması olduğunu belirtmiştir. “ ...Buranın eve yakın olması, bedava olması, aletlerin serbest ve zaman sınırı olmadan kullanılması tercih edilmeyi sağlıyor..." Ev hanımı olan Gönül, bu alanı halkın katıımının ücretsiz olmasından dolayı tercih ettiğini belirtmiştir. Bu alanlar herhangi bir spor salonuna gitmeye gücü yetmeyen ve yeterince zamanı olmayan kadınların fiziksel aktivite intiyaçlarını gidermek açısından önemlidir.

Kadınların fiziksel aktivite yapmalarında rekreasyon alanlarını tercih etmelerinde alanın sağlık açısından uygun olması, özellikle ekonomik gelir kaynağı sınırlı olan ya da hiç olmayan kadınlara ücretsiz fiziksel aktivite yapma ve farklı insanları tanıma fırsatı sunması etkilidir.

$\mathrm{Bu}$ alanların tercih edilmesini cazip kılan özelliklerin olmasının yanı sıra, kadınların bu alanlarda fiziksel aktivite yaparken karşılaştıkları bir takım sorunlar da mevcuttur. Bu sorunlara ilişkin kategoriler Tablo 4'te sunulmuştur.

Tablo 4'teki bulgular, kadınların rekreatif alanlarda fiziksel aktivite yaparken karşılaştıkları sorunların iki kategori altında ele alındığını göstermektedir. Bu sorunlar, "Fiziksel alan yetersizliği $(f=7)$ " ve "çevresel faktörlerin etkisi $(f=4)$ " olmak üzere iki kategoriden oluşmaktadır. Fiziksel alan yetersizliği, rekreatif alanının ko-

Tablo 4. Rekreatif Alanlarda Karşılaşılan Sorunlar

\begin{tabular}{ccccccccc}
\hline Kategoriler & & \multicolumn{1}{c}{ Katılımcılar } & Frekans \\
\hline & Hülya & Elif & Zahide & Gönül & Meltem & Zeynep & Sevinç & Şengül \\
\hline $\begin{array}{c}\text { Fiziksel Alan } \\
\text { Yetersizliği }\end{array}$ & $\checkmark$ & & $\checkmark$ & $\checkmark$ & $\checkmark$ & $\checkmark$ & & $\checkmark$ \\
\hline $\begin{array}{c}\text { Çevresel } \\
\text { Faktörlerin Etkisi }\end{array}$ & & & & $\checkmark$ & $\checkmark$ & $\checkmark$ & 4 \\
\hline
\end{tabular}


numlandırıldığı yerin uygun olmayışı, spor araç ve gereçlerinin yetersizliği ve bu araç-gereçlerin kullanımında yaşanılan bilgi eksikliği, fiziksel aktivite yapılan alanın talebi karşılamada yetersizliği gibi faktörleri içermektedir.

Fiziksel alan yetersizliği olarak kadınların geneli, yürüyüş parkurunun kısa olmasını ve araç-gereç eksikliğini belirtmiştir. Elde edilen bulgular, kadınların bu alanda daha çok yürüyüş parkurunu kullandıklarını ortaya koymuştur. Talep fazlalığı, etkili alan kullanımını sınırlamakta olduğu ve mevcut spor araç gereçlerinin yetersizliğine neden olduğu tespit edilmiştir. Örneğin Elif, yürüyüş parkurunu yetersiz bulduğu ve insanların rahat hareket edemediklerini belirmiştir.

“... Yürüyüş yapılan alan çok dar ve kısa, bu yüzden rahat hareket etme olasılığı olmuyor. Daha uzun olabilirdi Kırıkkale adına diye düşünüyorum... Çünkü bu alanlar insanların dışarıda hareket edebildikleri ve kendilerini özgür hissettikleri alanlar"(Elif).

“ ...Fiziki koşulların uygun olmayışından dolayı, birçok arkadaşım spor yapmak istemesine karşın bu alanın yol üstü olması ve alanın dar olmasından dolayı büyük sorun oluyor..." (Gönül). Alanın dar olması insanların bu alanı kullanımında problem olmaktadır. Ayrıca spor araç ve gereçlerinin de yeterli sayıda olmaması ve nasıl kullanılacağının bilinmemesi de katıımcıların rekreasyon alanlarında karşılaştıkları fiziki problemlerdir. Örneğin Şengül, araç-gereçlerin yeterli olmadığını, kendi dahil kimsenin aletlerin nasıl kullanacağı konusunda yeterli bilgiye sahip olmadığını belirtmiştir. "...Araç-gereçler az. Insanlar onları kullanma fırsatı bulamıyor. Araç-gereçler az olduğu için sınırlı kullanım oluyor. Bu yüzden onları doğru kullandığımı düşünmüyorum. Ama bu konuda da bilgilendirici çalışmalar yok. insanlar kullanıyorlar doğru ya da yanlış. Hatta insanlar birbirleriyle kavga bile ediyorlar. Sen çok kullandın diye". Örneğin aletlerin kullanımındaki bilgi eksiliğini Hülya şöyle ifade etmiştir: "Araç-gereçler var ama nasıl kullanılacak fikrim yok. Onları kafama göre kullanıyorum..." Belirli amaç için (kilo ver- mek, sağlıklı olmak vb.) rekreasyon alanlarında fiziksel aktivite yapan kadınların bu amaçlarına ulaşma noktasında, bu alanların bulundukları konum ve fiziki şartlar olarak iyi dizayn edilmiş olmalıdır. Bu durum kadınların spor etkiliklerine katıımında etkilidir. Bu alanın kadınların özellikle üzerinde durdukları kilo problemine çözüm üretebilmektedir. Kadınların beklentileri bu doğrultudadır. Örneğin Elif, kadınların kilo problemlerini azaltmada etkili olan araç-gereçlerin bu alanlarda mevcut olması, onları fiziksel aktivite yapmadaki öneminden bahsetmiştir. "... değişik faaliyetler yapılarak kadınların rahatsız oldukları kilo sorununun çözümüne ilişkin çeşitli aletler kurulsa ve de bu aletlerin uzman kişiler eşliğinde düzenlense kadınların katıımını artabilir". Elif'in de belirttiği gibi kadınların kilo problemini ortadan kaldırmak için bu alanlara katıım sağlamaktadır. Bunun için bu alanların kadınların faydalanabileceği şekilde düzenlenmelidir.

Kadınların rekreasyon alanlarında fiziksel aktivite yapmalarını engelleyen bir diğer faktör ise, bu alanın etrafındaki çevresel unsurlardır (Kahvehanelerin olması, halkın merak dolu bakışları, spor alanının etrafındaki binalar ve dükkanlar, bu alanda spor yapmadan oturan kişiler). Örneğin Meltem, erkeklerin spor yapmadan o alanda bulunmalarından duyduğu rahatsızlığı şöyle ifade etmiştir:

“...Etraftaki bakışlar da bizler için problem. Genellikle erkekler bu alana gelip oturuyor. Kadınlar ise bu durumdan rahatsızık duyuyorlar. Spor yapmayan insanların burada ne işi var, ne oturuyorsunuz, sizin ne işiniz var. Üstelik kahvehane de hemen karşıda buraya gelip oturmalarına gerek yok o mesafeden de rahatıkla izliyorlar". Ayrıca Meltem'in belirttiği bir diğer çevresel problem ise, bu alanın etrafında bulunan kahvehanelerdir. Alanın etrafında bulunan kahvehaneler ve binalar, kadınların rahat aktivite yapmalarında engel olduğu tespit edilmiştir. Bu alanın çevresel yapısındaki problemleri bilen ve tanık olan erkekler ise kadınlarının bu alanda aktivite yapmasını sınırlandırmaktadır. Elif bu konuyla ilgili durumu şöyle ifade etmiştir: 
“...Çoğu kadının eşi bu alanın etrafındaki rahatsız bakışlardan ötürü eşlerinin bu alanlarda fiziksel aktivite yapmalarına izin vermiyor. Komşum spor yapmak istemesine rağmen, etrafta binalar ve dükkanlar olduğundan eşi onu göndermiyor. Bu yüzden bu alanlar yapılırken fiziksel aktivite yapan kişilerin rahatsız edici unsurlardan arınık olmasına özen gösterilmelidir..."

Ev hanımı olan Zeynep, bu alana gelirken çevresel faktörlerden dolayı tedirginlik yaşadığını, bu nedenle yalnız olarak fiziksel aktivite yapmadığını ileri sürmüştür.

"Bu alanın etrafı iş yerleri ve apartmanlarla dolu bir yere yapılması ve bunun sonucunda insanların bakışlarının üzerimizde olması bizi tedirgin ediyor. Bu yüzden spor yaparken yalnız gelmiyorum. Eşim bazen benimle geliyor. Bazen de arkadaşlarımla geliyorum..."

Özellikle kadının toplumdaki yeri ve rolünün sınırlı olduğu ve erkek egemenliğinin hakim olduğu toplumumuzda kadınların aktivite yapma durumlarında eşlerinin bakış açısının önemli olduğu söylenebilir. Culp (1998), cinsiyetin sosyal etkinin oldukça önemli bir parçası olduğu ve bireylerin serbest zaman faaliyetlerini sınırlayan önemli bir unsur olduğunu belirtmiştir. Waren (1990), serbest zaman faaliyetlerine katılmada, kadınların erkeklere nazaran daha az fırsat ve olanağa sahip olduğunu, bunun da kadının toplumdaki yerinden kaynaklandığını belirtmiştir.

Fiziksel aktivite yapılan alanın kişinin beklentilerini karşılayıcı nitelikte organize edilmesi, bu alanlardan en etkili şekilde faydalanmada önemlidir. Kadınların daha aktif bir hayata kavuşmaları amacıyla fiziksel aktivitelerin önündeki engelleri azaltmak ve hareket özgürlüğünün sağlanması açısından bu alanların yeterliliğinin sorgulanması ve kadınların çevre baskısına maruz kalmadan, rahat hareket edebilecekleri alanların yaratıması ve bu alanların etkili araç ve gereçlerle donatıması daha fazla kadının bu alanlarda spora katılımını sağlamaktadır.

Tablo 5'te, kadınların rekreatif alanlarda karşılaştıkları sorunlara yönelik çözüm önerileri gösterilmiştir. Bu çözüm önerileri fiziksel ve çevresel unsurların düzenlenmesini içermektedir. Kadınların çoğu fiziksel açıdan fırsatların iyileştirilmesinin önemine vurgu yaparak, fiziksel aktivite alanlarının talebi karşılayacak şekilde büyütülmesi ve şehrin farklı yerlerine konumlandırıması gerektiğini ifade etmişlerdir. Özel-

Tablo 5. Rekreatif Alanlarda Karşılaşılan Sorunlara Yönelik Çözüm Önerileri

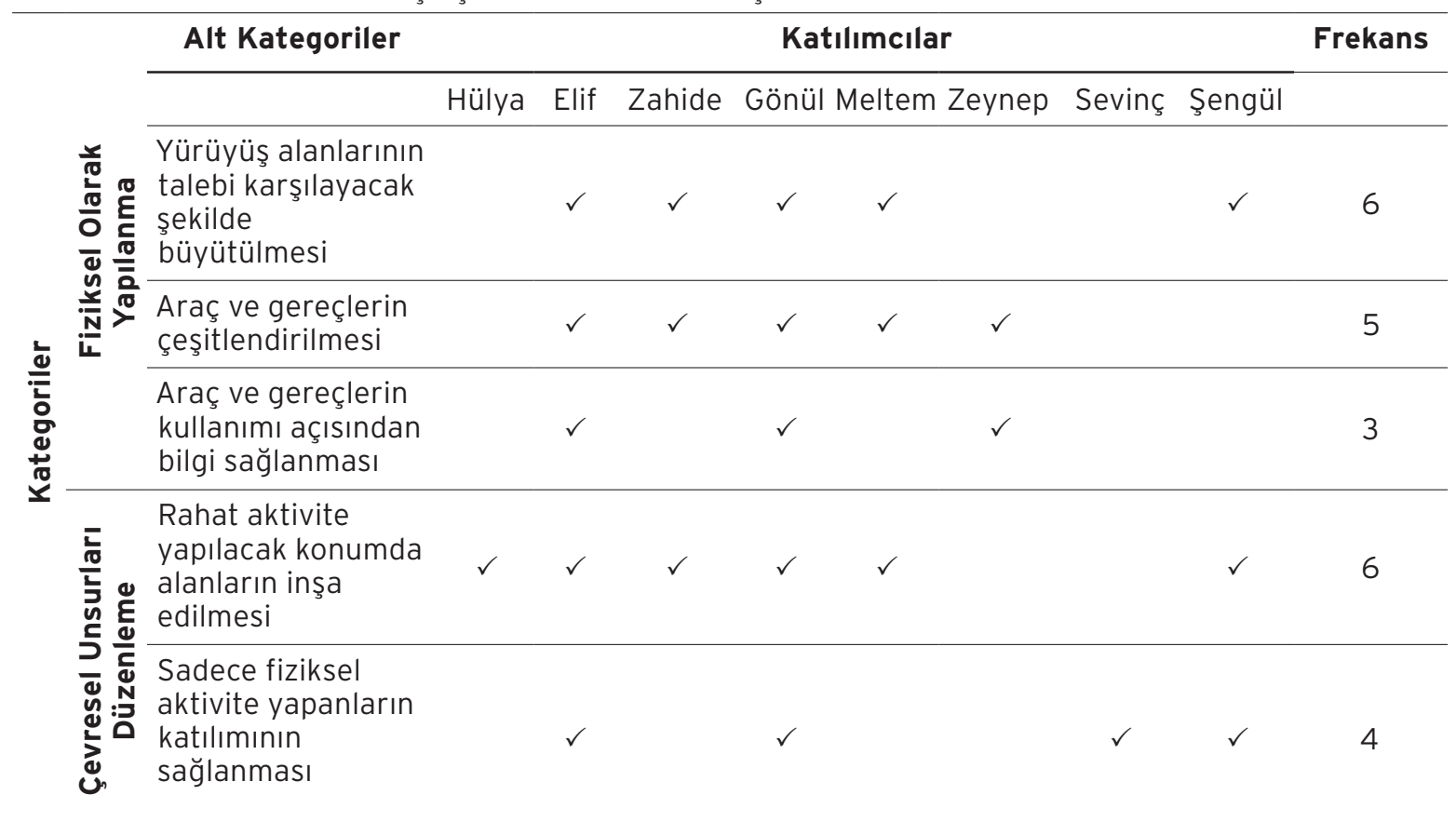


likle zamanının çoğunu ev işleri ile geçiren kadınların bu aktivitelere katılım sağlamalarında, bu alanların fiziksel ve çevresel olarak katılım sağlayacak şekilde düzenlenmesinin önemi üzerinde durmuştur. Hülya'nın buna yönelik görüşü şöyledir: "...Bu alan kişilerin katııımını sağlamak için yeterli değil. Şehrin farklı yerlerinde alanlar yapılacak olursa, daha fazla insan katılımı olur. Örneğin bu yürüyüş alanı kısa, hani daha uzun olsa yol kenarında ve apartmanların içerisinde değil de insanların daha rahat özgür bir şekilde hareket edebileceği alanlar genişletilebilir". Fiziksel olarak alanın yetersizliğini ifade eden Zahide, aletlerin yetersiz olduğunu ve çeşitlendirilmesi gerektiğini ifade etmiştir. "...Spor yaptığımız alan fiziksel olarak yetersiz. Tüm vücudun çalışması için yeterli araç gereç yok. Aletler yetersiz. Bu yüzden vücudumuzun bölgesel olarak çalışmasına neden oluyor. Karın kasları için alet var. Bacak kasları ve kol kaslarını çalıştırıcı alet yeteri kadar yok benim sorunum o..." Gönül'ün bu konudaki görüşü Zahide'nin görüşü ile benzerlik göstermektedir. "...Vücudun değişik bölgelerini çalıştıran aletler konulabilir. Çünkü burada hem erkek hem kadın karışık spor yapıyoruz. Dolayısıyla aletler ve alan yetersiz olunca aktivite yapma alanımız kalmıyor. Oysaki çoğu insan burada yürüyüş parkurunu kullanıyor. Birkaç tane daha yürüyüş parkuru yapılabilir..." Fiziksel olarak aletlerin yetersiz olduğunu ifade eden kadınlar aletlerin kullanımına yönelik yeterli bilgilerinin olmadığını, aletlerin nasıl kullanılacağına yönelik bilgilendirmeleri içeren çalışmalar yapılması gerektiğini ifade etmişlerdir. Zeynep, bu alandaki spor aletlerinin nasıl kullanılacağını bilmediğini ve gelişigüzel yaptığını belirtmiştir. “...Aletler yeterince yok. Ama olanları da kullanmada sıkıntı yaşıyorum ki çoğu kişinin de bilgisinin olmadığını düşünüyorum. Aletlerin yanına bilgilendirmek için talimat konulabilir. Ya da bu alanlarda uzman kişilere mi yer verilse..."

Çevresel faktörlerin fiziksel aktivite yapma üzerindeki olumsuz etkisini ifade eden kadınlar, bu alanların spor yapmayan kişiler tarafından gözlemlenmesi, kahvehane gibi mekânlara yakın olmasının kadınların katılımlarını sınırlan- dırdığını belirtmişlerdir. Bu nedenle kadınlar bu alanlarda sadece aktivite yapanların olması gerektiğini, meraklı bakışlardan soyutlanması gerektiğini belirtmişlerdir.

Meltem, çevresel faktörlerin fiziksel aktivite üzerindeki olumsuz etkisini yok etmek amacıyla şu öneriyi sunmuştur. "...Ş̧ehrin gürültüsünden ve yolun bulunduğu alandan uzak olmalı. Bu aktivitelerin sürekli yapılabilmesi için mevsimsel yapılmasını engellemek için kapalı alanlar inşa edilebilir. Yağmur yağınca dışarı çıkamıyoruz. Bu alanların da sadece üstü kapalı olması iyi olur. Aksi takdirde diğer spor salonlarından farkı kalmaz..." Ayrıca bu alanlarda erkek ve kadın birlikte aktivite yapılmasından ve çevrede aktivite yapmayan erkeklerin bakışlarından rahatsızlık duyan Meltem'in bu konuya yönelik önerisi şöyledir: "...Camlı olsa dışarıdakiler içerdekileri görmese daha mı iyi olur. Çünkü Kırıkkale insanlarının merakları var ya bu sıkıcı. Bizler bayan olarak bile birbirimizi eleştiriyoruz. A şu kilo almış, aman şu zayıflamış ben bile diyorum. Erkeğin demesi ve izlemesi de normal bir durum... Hemcinslerimizin de bizleri eleştirdiği zamanlar oluyor. Hatta şunu bile diyorlar. Yürüyorsunuz, yürüyorsunuz aynı duruyorsunuz. Yani erkekten önce kadın kadına yorum yapıyor..."

Sonuç olarak fiziksel aktiviteye kadınların katıımının sağlanmasında fiziksel açıdan onları motive edebilecek ve olumsuz çevre koşullarını en aza indirgeyerek kadınların bu alanlara katıIımını sağlayıcı aktivitelerle onlara sosyalleşme ve özgüven duygusu kazanmalarına fırsat sunan alanlar oluşturularak, toplumda daha aktif yer edinmeleri sağlanabilir.

\section{TARTIŞMA}

Toplumda fiziksel aktiviteyi halkın günlük yaşantısının bir parçası haline getirmek amacıyla "Sağlıkı yaşam için spor" ve "Herkes için spor" gibi projelerle halk fiziksel aktiviteye teşvik edilmeye çalışıımıştır. Halkın rahatlıkla aktivitelere katılabilmesi için yerel yönetimler tarafından açık alan egzersiz parkları oluşturulmuştur.

Kadınların serbest zaman aktivitelerine katılımında fiziksel aktivitenin yeri ve yerel yöne- 
timlerin sunduğu rekreatif alanlara katılım du rumları ve karşılaşılan sorunların tespit edilmesi açısından önem arz eden çalışmada, kadınların bu aktivitelere katılma nedenleri arasında ilk sırayı sağııkı olma nedeni yer almıştır. Hareketin, aktivitenin ve aktif yaşamın kendilerine fiziksel, sosyal, psikolojik olarak katkı sağladığına inanan kadınlar, sağlıklı bir hayat sürdürmek için fiziksel aktiviteyi yaşamlarının vazgeçilmez unsuru olarak nitelendirmektedir. Sağlık, "genç", "zayıf" ve "formda" olmak biçiminde yeniden tanımlanmakta, bireylere bu tanıma uygun, "sağlıklı" bedene ulaşmanın yolları sunulmaktadır. "Ruhsal ve fiziksel tam iyilik hali "nin karşılığı bu koşullar altında yeniden oluşturulmaktadır (Sezgin, 2011). Araştırmada kadınlar zayıf olmayı sağlığın ön koşulu olarak nitelendirmektedir. Kadınların öncelikli olarak sağlıkı olmak amacıyla spor yaptıkları bulgusu, Mengütay ve diğ. (2006)'nin çalışmasında da elde edilen bulgu ile benzerlik taşımaktadır. Çalışmada fiziksel aktivite yapma nedenleri arasında sağlık \%10,7 ile ilk sırada yer almıştır. Korucu Aytan (2013)'ın kadınların spora olan ilgilerini incelediği çalışmada benzer bulgu elde edilmiştir. Spor yapan ve yapmayan kadınlar üzerinde sporun etkisi incelenen çalışmada, spor yapan kadınların kendilerini yapmayanlara göre daha sağlıkı hissettikleri tespit edilmiştir. Amman (2005)'in kadınların spor yapma amaçlarını incelediği çalışmadan elde ettiği sonuçlarda mevcut çalışmamızda elde edilen bulgular ile paralellik göstermektedir. Çalışmada sırasıyla; sağlıklı olmak, düzgün bir vücuda sahip olmak, stres atmak, mutlu olmak ve eğlenmek, arkadaş kazanmak, grup duygusunu yaşamak gibi amaçları içermektedir. Kadınların fiziksel aktivite yapma nedeni olarak sağlıklı olmayı kilo verme, kiloyu dengede tutma ve iyi bir görünüşe sahip olmayı içeren fiziksel görünüş takip etmektedir. İlgili alan yazında rekreasyonel amaçlı fiziksel aktiviteye katılımda; sağlığın yanı sıra, dış görünüm ve sosyalleşme gibi çeşitli faktörlerin de etkili olduğu ortaya çıkmıştır (Gürbüz, 2012). Öztürk ve diğ. (2013)'nin sabah sporlarına katılan ev hanımlarının spor konusundaki görüşlerini incelediği çalışmada, kadınların spor yapma amacı
\% 61'i sağlık ve \% 17'i kilo vermek olduğu bulgusu elde edilmiştir. Kadınların fiziksel aktivite yapma amaçlarının öncelikli olarak sağlıklı olma, bunu ise fiziksel görünüm izlemektedir. Mevcut çalışmamızda ve ilgili alan yazında fiziksel aktivitenin kilo verme ile eşleştirildiği görülmüştür (Öztürk ve Koca, 2014; Hacısoftaoğlu ve Bulgu, 2012). Kadının toplumdaki rolü dikkate alındığında, onların ev içi sorumlulukları ve toplumda kadına yönelik annelik ve eşe karşı sorumluluk kendilerine zaman ayırabilme noktasında sınırlılık getirmektedir. Bourdieu (1978)'ye göre, ev kadınlarının bedenleriyle kurdukları ilişkide ev halkının intiyaçlarını karşılamak görevinin belirlediği araçsal bir ilişki olmakta ve işçi sınıfı ev kadınları ve anneler, kocaları ve çocuklarının ihtiyaçlarını karşılamak için kendi bedenlerini kurban etmektedirler. Onların üstlendikleri roller gereği (anne, eş, iş hayatı vb. gibi) kendilerine zaman ayırma noktasında daha kısıtı fırsatlara sahiptirler (Ardahan ve Yerlisu Lapa, 2011). Çünkü kadının toplumdaki temel rolünün ev işleriyle uğraşmak ve çocuk büyütmek olduğu, bunun da kadınların serbest zaman faaliyetlerine katılmalarını etkilemekte ya da sınırlandırmaktadır. Katılımcıların çoğunluğunun ev hanımı oldukları dikkate alındığında, çocuk bakmak ve ev işleri ile ilgilenmek zorunda olan kadınların kendilerine bakmak için yeterince zaman ve fırsat sahibi olmadıkları görülmüştür. Kadınların annelik ve ev hanımlığı vasfı bulunması, eşleri ve çocuklarına karşı sorumluluklarının olması, kendilerine ayıracakları zamanı sınırlamaktadır.

Sosyalleşme ve stresten uzaklaşma katılımcıların spor yapma nedenleri arasında öne çıkan diğer unsurlardır. Tatar ve diğ., (2009)'nin çalışan ve çalışmayan kadınların spor yapmalarını etkileyen faktörleri inceledikleri çalışmada da, kadınların sporu günlük sıkıntılardan uzaklaşmak ve sosyal çevre edinmek amacıyla yaptıkları belirlenmiştir. Kadınlara yüklenen görev ve sorumluluklar, çalışan kadının çalışma temposu dışında ev işlerine ve çocuklarına zaman ayırma$\mathrm{SI}$, onların sorumluluklarını yerine getirme noktasında problem yaşamalarına neden olmaktadır (Theberge, Curtis ve Brown, 1982). Mevcut 
çalışmamızda katılımcıların çoğunluğunun ev hanımı olduğu göz önünde bulundurulduğunda, toplumdaki rol ve görevlerini yerine getirme noktasında stres yaşadıkları elde edilmiştir. Bu amaçla kendilerini özgür hissedebilecekleri, arkadaşlarıyla zaman geçirebilecekleri ve sıkıntılarını giderebilecekleri etkinlik olarak fiziksel aktiviteyi tercih ettikleri görülmüştür. Ayrıca Reiger ve diğ., (1988)'ne göre; fiziksel aktiviteye katıımın kaygı ve depresyon gibi stresle ilgili problemleri azaltmaktadır.

Mevcut çalışma, kadınların fiziksel aktiviteye katıımda açık alan egzersiz parklarını tercih etme nedenleri olarak; bu alanların sağlık, fiziksel, sosyalleşme ve maddi açıdan uygun olduğunu ortaya koymuştur. Açık alanın insan sağlığı ve psikolojisi üzerinde olumlu etkisinin olması, farklı insanlarla tanışma fırsatı sunması ve özellikle bu alanların halka açık olması ve halkın bu alanları kullanabilmesi için herhangi bir ücret ödememesi tercih edilmesinde önemli unsurlardır. Rekreasyon alanları kent insanına doğal çevreyi en iyi sunabilen alanlardır. Çalışmamızda kadınların bu alanları tercih nedenleri olarak temiz hava, bol oksijen ve doğa ile baş başa olmaları olduğu belirlenmiştir. Bu nedenle insanlar bu alanları temiz hava ve doğal çekiciliklerinden dolayı tercih etmektedir (Erdinç, 1999). Ayrıca çalışmamızda, çalışmayan kadınların insanlarla sosyalleşebilmeleri, farklı ortamlarda bulunmaları ve farkı kişileri tanımak amacıyla bu alanlara katıım sağladıkları tespit edilmiştir. Bulgu ve diğ., (2007)'nin kadınların rekreatif düzeyde fiziksel aktivite yapma nedenlerini inceledikleri çalışmada, kadınların bu etkinlikler sayesinde ev dışına çıktıkları ve yeni arkadaşlıklar ve ortamlar edindikleri bulgusu elde edilmiştir.

Kadınların fiziksel aktivite yaparken karşılaştıkları problemler ise fiziksel ve çevresel olarak kategorize edilmiştir. Fiziksel olarak yürüyüş parkurunun kısa ve yetersiz olması, spor aletlerinin yetersiz olması, aletleri kullanmaya yönelik bilgi yetersizliği, konumlandırıldığı alanın trafiğe ve iş yerlerine yakın olması gibi konuları içerirken, çevresel olarak ise meraklı bakışların olması ve kahvehanelere yakın olması gösterilmiştir.
Katılımcılar genel olarak yürüyüş parkuru yetersizliğini ve spor yapmayanların kendi üzerlerindeki bakışlarından rahatsızıklarını ifade etmiştir. Elde edilen bulgular, çevresel problem olarak nitelendirilen bu durumda, fiziksel aktivite yapmak isteyen kadınların eşleri sınırlandırma getirmesiyle karşı karşıya kaldıklarını göstermiştir. Ceylan ve diğ. (2010)'ne göre, bazı ülkelerde toplum baskısı, din ya da aile faktörlerinin etkisiyle kadınlar sportif aktivitelere sınırlı katıım sağlamaktadır. Mevcut çalışmada elde edilen bulguya göre kadınlar bu alanlarda arkadaş, eş ya da çocukları ile birlikte katılım sağlamaktadırlar. Benzer sonuç Krenichyn (2004)'ın şehir parkındaki kadın ve fiziksel aktivite konulu çalışmasında elde ettiği çalışma ile benzerlik taşımaktadır. Çaışmada kadınların aktivitelere aile veya arkadaş ile katılım sağlamaları, kendileri için güvenilir ortam sağladığı bulgusuna ulaşmıştır. Ağılönü ve Mengütay (2009)'ın çalışması neticesinde serbest zaman faaliyetlerine kişilerin \%45,7'si eşi ve çocukları ile\%20,8'i ise arkadaşları ile katıım sağladıkları görülmüştür. Mevcut çalışmamız bu çalışmalarla benzerlik göstermektedir. Kadınların etraftan rahatsız oldukları için arkadaş, eş ve çocukları ile birlikte aktivite yaptıkları görülmüştür.

Aletlerin yetersizliği ve kadınların aletleri kullanma konusunda yeterince bilgiye sahip olmaması yönünde de eksiklikler tespit edilmiştir. Şimşek ve diğ. (2011)'nin açık alan egzersiz parkları ve kullanıcılarına yönelik yaptıkları çaIışmada; bireylerin \%83'ünün park alanlarındaki egzersiz aletlerini yetersiz bulduğu ve \%98'inin ise yürüyüş ve koşu alanına intiyaç duyduğu, ayrıca park alanı içerisindeki aletlerin kullanımı konusunda yeterli bilgiye sahip olmadığı neticesini elde etmişlerdir. Bu açıdan mevcut çalışmamız ile benzerlik göstermektedir.

\section{SONUÇ ve ÖNERILER}

Kadınların fiziksel aktivite tercihlerinde sağlık ve fiziksel görünüşün etkili olduğu, kadınların eğitim durumları ve mesleklerinin fiziksel aktivite alanı olarak rekreasyon alanlarını tercih etmelerinde önemli değişkenler olduğu, ev ha- 
nımlarının bu alanlarda farklı kişilerle tanışma olanağı bulduğu, böylece kendilerine sosyalleşme alanı olarak bu alanların faydalı olduğu söylenebilir. Kadınların açık alanda fiziksel aktivite yapmalarında fiziksel ve çevresel bazı problemler yaşadıkları, özellikle bu alanların konumlandırıldığı mekanlardaki apartman, kahvehane gibi çevresel olarak nitelendirebileceğimiz unsurlardan rahatsızlık duydukları, kadınların bu nedenden dolayı sınırlı oranda bu alanlara katılım sağladıkları belirlenmiştir. Bu alanlarda yeterli araç-gerecin olmaması ve kadınların onları nasıl kullanacağını bilmemesi rekreasyon alanında karşılaşılan problemlerdir. Bu çalışma kapsamında aşağıdaki öneriler getirilebilir:

- Bu alanları aktif olarak kullanan kadınların bilinçlendirilmesi amacıyla aletlerin nasıl kullanılması gerektiğine yönelik bilgilendirici çalışmalar yapılabilir.
- Bu alanlar inşa edilirken fiziksel ve çevresel uygunluk açısından yerel yönetim spor bilimcileri ile birlikte işbirliği yapabilir.

- Bu alanlar inşa edilmeden kamuoyu görüşü alınarak kadınların da nasıl bir ortamda aktivite yapmak istediklerine yönelik beklenti ve istekleri tespit edilebilir.

- Çalışmaya erkekler dâhil edilerek onların da bu alanlarda fiziksel aktivite yapmalarına yönelik görüşleri tespit edilebilir.

\section{Yazıșma Adresi (Corresponding Address):}

\section{Arş. Gör. Mehmet ULAŞ}

Mehmet Akif Ersoy Üniversitesi, Beden

Eğitimi ve Spor Yüksekokulu

E-posta:m.ulas@yahoo.com.tr,mulas@

mehmetakif.edu.tr

Telefon No: 02482134643

\section{K A Y N A K L A R}

1. Ağılönü A, Mengütay S. (2009). Yerel Yönetimlerde Rekreasyon Hizmetleri ve Model Belirleme. Uluslararası insan Bilimleri Dergisi, 6(2), 160-176.

2. Amman MT. (2005). Kadın ve Spor. Morpa, İstanbul.

3. Angevaren, M., Aufdemkampe, G., Verhaar, H.J., Aleman, A., \& Vanhees, L. (2008). Physical activity and enhanced fitness to improve cognitive function in older people without known cognitive impairment. Cochrane Database of Systematic Reviews, 3, CD005381. PubMed

4. Ardahan F, Yerlisu Lapa T. (2011). Açık alan Rekreasyonu: Bisiklet Kullanıcıları ve Yürüyüşçülerin Doğa Sporu Yapma Nedenleri ve Elde Ettikleri Faydalar. Uluslararası Insan Bilimleri Dergisi, 8(1).

5. Ardahan F. (2013). Bireyleri Rekreatif Spor Aktivitelerine Motive Eden Faktörlerin REMM Ölçeği Kullanılarak Çeşitli Demografik Değişkenlere Göre incelenmesi: Antalya Örneği, Pamukkale Spor Bilimleri Dergisi, 4(2), 1-15.

6. Arslan B., \& Koca C. (2006). Kadın sporcuların yer aldığı günlük gazete haberlerinin sunum biçimine dair bir inceleme. Spor Bilimleri Dergisi: Hacettepe Üniversitesi, 17(1), 1-10.

7. Aytan Korucu G. (2013). Kadınların spora olan ilgilerinin incelenmesi. Kastamonu Üniversitesi Kastamonu Eğitim Dergisi, 21(2), 777.
8. Bourdieu P. (1978). Sport and social class. Social Science Information, 17(6), 819-840.

9. Baş T, Akturan U. (2013). Nitel Araştırma Yöntemleri: Nvivo ile Nitel Veri Analizi, Örnekleme, Analiz, Yorum. Ankara: Seçkin Yayınları.

10. Bek N.(2008). Fiziksel Aktivite ve Sağlığımız. Ankara: Sağıık Bakanlığı Yayınları.

11. Bogdan R., \& Biklen SK. (2003). Qualitative research for education. Boston: Allyn \& Bacon.

12. Bulgu N, Koca Arıtan C, Aşçı FH. (2007). Gündelik Yaşam, Kadın ve Fiziksel Aktivite. Hacettepe Spor Bilimleri Dergisi, 18(4),167-181.

13. Cantek F., \& Yarar B. (2009). Erken cumhuriyet dönemi dergi ve gazetelerinde spor ve kadın (1928-1960). İletişim Kuram ve Araştırma Dergisi, (29), 201-218.

14. Ceylan M, Tekin A, Özdağ S, Ceylan ö. (2010). Uçurtma ve Rüzgar Sörfü Yapan Bireylerin Bazı Kişilik Özelliklerinin Karşılaştırılması. Türkiye Kickboks Federasyonu Spor Bilimleri Dergisi, 2(2), 52-66.

15. Culp RH. (1998). Adolescent girls and outdoor recreation: A case study examining constraints and effective programming. Journal of Leasure Research, 30(3), 356-379.

16. Creswell JW. (2013). Nitel Araştırma Yöntemleri: Beş Yaklaşıma Göre Nitel Araştırma Deseni. (Çev. Ed. Mesut Bütün ve Selçuk Beşir Demir). Ankara: Siyasal Kitabevi. 
17. Ekiz D. (2009). Bilimsel Araştırma Yöntemleri. Ankara: Anı Yayıncılık.

18. Erdinç G. (1999). Kentsel ve Kırsal Rekreasyon, Tarım ve Köy İşleri Dergisi, 129, 30-32.

19. Filiz, Z. (2005). Illlerin Sosyo-Ekonomik Düzeylerine Göre Gruplandırılmasında Farklı Yaklaşımlar. Eskişehir Osmangazi Üniversitesi Sosyal Bilimler Dergisi, 6(1).

20. Gökçe 0. (2006). İçerik Analizi Kuramsal ve Pratik Bilgiler. Ankara: Siyasal Kitabevi.

21. Günay G., \& Bener ö. (2011). Kadınların toplumsal cinsiyet rolleri çerçevesinde aile içi yaşamı algılama biçimleri. Türkiye Sosyal Araştırmalar Dergisi, 153(153).

22. Gürbüz B. (2012). Exercise Participation Motives: A Case of Turkish Participants, Energy Education Science and Technology. Social and Educational Studies, 4(3), 1197-1208.

23. Hacısoftaoğlu i., \& Bulgu N. (2012). Kadınlar ve Egzersiz: Spor Merkezlerinde Aerobik Egzersizin Çatışmalı Anlamları. Hacettepe Üniversitesi Spor Bilimleri Dergisi, 23(4), 177-194.

24. Heyward VH. (1991). Advanced fitness assessment and exercise prescription. Second Edition.Human Kinetics, Champaign, Illinois.

25. Karakuş S. (2005). Beden Eğitimi ve Spor Yüksek Okulunda Okuyan Öğrencilerin Fiziksel Sağlıkları ile Serbest Zaman ve Sigara Kullanımı arasındaki ilişkinin incelenmesi, Gazi Üniversitesi Kırşehir Eğitim Fakültesi, 6(2), $1-13$.

26. King K. (2000). From the precipice: Recreation experiences of high-risk adolescent girls. Journal of Park ve Recreation Administration, 18(3),19-34.

27. Koca C, Hendersen KA, Aşçı FH, Bulgu N. (2009) Constraints to leisure-time physical activity and negotiation strategies in Turkish Women. Journal of Leisure Research, 41(2),225-251.

28. Koca, C. (2006). Beden eğitimi ve spor alanında toplumsal cinsiyet ilişkileri. Hacettepe Üniversitesi Spor Bilimleri Dergisi, 17(2), 81-99.

29. Koruyucu Aytan G. (2013). Kadınların Spora Olan İlgilerinin İncelenmesi. Kastamonu Eğitim Dergisi, 21(2),777-790.

30. Krenichyn K. (2004). Women and physical activity in an urban park: Enrichment and support through an ethic of care. Journal of Environmental Psychology, 24(1),117-130.

31. Mansuroğlu S. (2002). Akdeniz üniversitesi öğrencilerinin serbest zaman özellikleri ve dış mekan rekreasyon eğilimlerinin belirlenmesi. Akdeniz Üniversitesi Ziraat Fakültesi Dergisi, 15(2), 53-62.

32. Mengütay S, Zorba E, Ağılönü A, Cerit E, Ağılönü ö. (2006). Yerel yönetimlerde çalışanların katıldıkları rekreatif aktivitelere yönelten nedenler ve kazanımları (Muğla belediyesi örneği). 9. Uluslararası Spor Bilimleri Kongresi, 3-5 Kasım, Muğla.

33. Merriam SB. (2013). Nitel Araştırma: Desen ve Uygulama için Bir Rehber (Çev.Ed. Selahattin TURAN). Ankara: Nobel Yayın.
34. Miles MB, Huberman AM.(1994). Qualitative Data Analysis (Second Edition). United Kingdom: Sage Publication.

35. North TC, McCullagh P, Zung VT. (1990). Effect of exercise on depression. Exercise and Sport Sciences Reviews, 18,379-415.

36. Oktan V, Şahin, M. (2010). Kız ergenlerde beden imajı ile benlik saygısı arasındaki

ilişkinin incelenmesi. Uluslararası İnsan Bilimleri Dergisi, $7(2), 543-556$.

37. Özbey S., \& Güzel P. (2011). Olimpik hareket ve kadın. Balikesir University Journal of Social Sciences Institute, 14(25), 1-18.

38. Özgüven, İE. (2004). Görüşme İlke ve Teknikleri. Ankara: Pegem Yayınları.

39. Öztürk P., \& Koca C. (2014). Egzersiz ve Performans Sporunda Beden Politikaları. Türk Tabipleri Birliği Dergisi, 29(5).

40. Öztürk E, Hanbay E, Kaya B. (2003). Sabah Sporlarına Katılan Ev Hanımlarının Spor Konusundaki Bilgiler, İlgiler ve Görüşlerinin İncelenmesi. İstanbul Üniversitesi Spor Bilimleri Dergisi, 11(3), 151-156.

41. Paffenbarger Jr, R. S., Hyde, R. T., Wing, A. L., Lee, I. M., Jung, D. L., Kampert, J. B. (1993). The association of changes in physical-activity level and other lifestyle characteristics with mortality among men. New England Journal of Medicine, 328(8), 538-545.

42. Patton MQ. (2001). Qualitative Evaluation and Research Methods. Newsbury: Sage

Publication

43. Punch KF. (2005). Introduction to Social ResearchQuantitative \& Qualitative Approaches. London: Sage.

44. Reiger DA, Boyd JH, Burke JD, Rae DS, Myers JK, Kramer ve diğ. (1988). One-month prevalence of mental disorders in the United States. Based on Five Epidemiologic Catchment Area Sites. Arch Gen Psychiatry, 45 (11), 977-86.

45. Riddoch C. (1998). Relationships between physical activity and physical health in young people. Young and active, 17-48.

46. Schmitter C. (2003). Life Satisfaction In Centenarians Residing In Long-Term Care. http://www.mmhc.com/ articles/NHM9912/cutillo.html, 19 Nisan 2011.

47. Sezgin D. (2011). Yaşam Tarzı Önerileri Bağlamında Sağlık Haberlerinin Analizi. Ankara Üniversitesi Sosyal Bilimler Enstitüsü Dergisi, 2(2), 52-78.

48. Şahin G, Özer $M K$, Söğütçü T, Bavlı Ö, Serbes Ş, Yurdakul Hö ve diğ. (2014). Kadınlarda Düzenli Fiziksel Aktivite Alışkanlığı. Uluslararası Hakemli Akademik Spor Sağlık ve Tıp Bilimleri Dergisi, 10(4),88-97.

49. Tatar G, Tozoğlu E, Pehlivan Z. (2009). 20-40 Yaş Arası Çalışan ve Çalışmayan Kadınların Spor Yapmalarını Etkileyen Bazı Faktörlerin İncelenmesi (Sivas il merkezi örneği). Atatürk Üniversitesi Beden Eğitimi ve Spor Bilimleri Dergisi, 11(3),28-41.

50. Theberge N, Curtıs JE, Brown BA. (1982). Studies in The Sociology of Sport. Fort Wort:Texas Christian University Press. 
51. US Dept of Health \& Human Services, United States. Public Health Service. Office of the Surgeon General, National Center for Chronic Disease Prevention, Health Promotion (US), President's Council on Physical Fitness, \& Sports (US). (1996). Physical activity and health: A report of the Surgeon General. International Medical Pub. Erişim: http://www.cdc. gov./nccdphp/sgr/pdf/execsumm.pdf 10.02.2016

52. Warren K. (1990): Women's outdoor adventures. In Miles, J. C. ve Priest, S. (Eds.), Adventure Education. State College, PA: Venture.

53. Weinberg RS., \& Gould D. (2014). Foundations of Sport and Exercise Psychology, 6E. Human Kinetics.
54. WHO (World Health Organization), (1998). Gender and Health, Technical Paper. Erişim:https://extranet.who. int/iris/restricted/handle/10665/63998 10.02.2016

55. Yaprak P., Amman M. T. (2009). Sporda kadinlar ve sorunlari. Turkiye Kick Boks Federasyonu Spor Bilimleri Dergisi, 2(1), 39-49.

56. Yıldırım A, Şimşek H. (2011). Sosyal Bilimlerde Nitel Araştırma Yöntemleri. (8.Baskı). Ankara: Seçkin Yayınları. 